\title{
16
}

\section{A Research-Based Rubric for Developing Statements of Teaching Philosophy}

\author{
Matthew Kaplan, Deborah S. Meizlish, \\ Christopher O'Neal, Mary C. Wright \\ University of Michigan
}

Despite its ubiquity as the way that instructors represent their views on teaching and learning, the statement of teaching philosophy can be a frustrating document to write and the results are often uneven. This chapter describes a rubric created at the University of Michigan's Center for Research on Learning and Teaching to help faculty and graduate students craft teaching statements. We describe the research that informed the creation of the rubric, talk about how we use the rubric in our consultations and workshops, and present an assessment that validates the use of the rubric to improve instructors' teaching statements.

$\mathrm{T}$ he statement of teaching philosophy or teaching statement has emerged as a standard piece of academic writing in which instructors articulate their beliefs about, approaches to, and accomplishments in teaching and learning. Numerous resources are available about how to write teaching statements, both in print form (e.g., Chism, 1997-1998; Coppola, 2000; Ellis \& Griffin, 2000; Goodyear \& Allchin, 1998) and on teaching center web sites across the country. These articles also point out the practical benefits of teaching statements (e.g., for job searches and as part of teaching portfolios) and their potential for enhancing reflective practice, making implicit ideas about teaching and student learning explicit, and helping college teachers align their beliefs and their pedagogical practices. 
Consultants at our teaching center have helped hundreds of graduate students and faculty write their own statements. As a result, we have come to agree that the process of writing a teaching statement can be quite valuable and lead to a document that provides needed insight into an instructor's pedagogical beliefs and behaviors. However, our experience has also shown that faculty and graduate students often find teaching statements difficult and frustrating to write and evaluate, and the quality of their efforts can be uneven despite the availability of resources and the genre's ubiquity. This frustration has led some academics to question the utility of teaching statements, criticizing them as empty, boilerplate, and uninformative (Montell, 2003; Pratt, 2005).

To remedy the problems associated with teaching statements, we crafted a rubric designed to guide authors through writing and editing their teaching statements and to help them give feedback to colleagues in workshops and seminars conducted by our center. The rubric's construction was informed by our own perceptions of what made for effective teaching statements and was later refined by a survey of search committee chairs' perceptions of the successful and unsuccessful qualities of teaching statements. The rubric has made the writing process more manageable by demystifying an unfamiliar genre that can seem overwhelming: The rubric's delineation of a fixed number of topics, along with clear criteria for each, helps writers focus their efforts.

In this chapter, we present evidence demonstrating the widespread use of teaching statements, discuss the development of the rubric, and then describe the various ways we use the rubric to help graduate students and faculty write their own teaching statements. We end with data from a brief assessment comparing clients' teaching philosophies in the pre-rubric and post-rubric eras, which appear to validate our approach.

\section{Research Overview}

\section{: Uses of Teaching Statements}

Teaching statements can be used for both formative and summative evaluation. As just described, writing a teaching statement entails reflection on current practice, a necessary part of formative evaluation and a prerequisite for deciding on areas for improvement. However, statements of teaching philosophy are better known for their use in summative types of evaluation, in particular in vetting job candidates for faculty positions and evaluating faculty work in teaching for promotion and tenure.

In an attempt to learn more about teaching evaluation practices, we gathered information in spring 2006 from peer institutions concerning teaching 
evaluation methods mandated by their central administrations (i.e., provosts). For the purposes of this study, we defined peer institutions as those campuses with whom the University of Michigan collaborates in consortia of teaching center directors-members of the Committee on Institutional Cooperation and the Ivy Plus groups-as well as other flagship state universities. For a full list, see Figure 16.1.

FIGURE 16.1

Peer Institutions for Teaching Evaluation Survey

\begin{tabular}{|llll|}
\hline Berkeley & Illinois & Northwestern & UNC \\
Brown & Indiana & Ohio State & UVA \\
Chicago & Iowa & Penn & Washington \\
Columbia & Michigan & Penn State & Wisconsin \\
Cornell & Minnesota & Princeton & Yale \\
Dartmouth & MIT & Purdue & \\
Harvard & Michigan State & Stanford & \\
\hline
\end{tabular}

We gathered data from university web sites and then asked colleagues at teaching centers on those campuses to check and supplement the information. In all, we collected data from 26 institutions, 14 of which (53\%) required some type of teaching statement for promotion and tenure (exact definitions and terminology varied and included self-evaluations, teaching philosophies, and comprehensive statements of a candidate's accomplishments in research, teaching, and service). Student ratings are the only type of evaluation required more frequently (18 universities, or 69\%). Replicating this process on our own campus, we learned that all schools and colleges required some form of teaching statement. While there are obvious limitations to this study in terms of scope, it is clear that including some form of teaching statement in the review process has become standard practice, even at research-extensive universities.

Writing a statement of teaching philosophy has also become an integral part of the faculty job search. Our teaching center, like others around the country, includes sessions on the teaching statement in our campus-wide Preparing Future Faculty (PFF) Seminar as well as in customized, disciplinespecific seminars. We also conduct numerous consultations with graduate students as they prepare their job applications.

To learn more about how graduate students use their statements, we did a follow-up survey of participants in our PFF Seminar, an intensive, monthlong program with a particular emphasis on preparing documents for the 
job search. The results of that survey indicated that $90 \%$ of seminar participants used their teaching statements for the job market (Cook, Kaplan, Nidiffer, \& Wright, 2001).

To determine the extent to which faculty search committees requested statements, two of the authors (Meizlish and Kaplan) conducted a survey of search committee chairs at colleges and universities across the country in spring and summer 2005. This survey was part of a larger project to examine the relative importance of teaching in faculty searches (for additional information on this study, see Meizlish \& Kaplan, 2007). We began by collecting job ads from disciplinary databases for tenure-track assistant professors or open-rank positions in six disciplines (biology, chemistry, English, history, political science, and psychology), and then drew a random sample of those ads in each discipline for our follow-up survey. Of the 755 committee chairs who received the survey, 457 responded, a $61 \%$ response rate. Of those surveyed, $57 \%$ overall indicated that they requested a teaching statement at some point in the job search. Tables 16.1 and 16.2 report percentages by institutional type and disciplinary division. Differences by institutional type were not statistically significant: $60 \%$ of master's and bachelor's institutions and approximately $54 \%$ of doctoral universities requested statements. The disciplinary differences were statistically significant and somewhat surprising: Approximately $50 \%$ of humanities and social sciences committees requested statements, while close to $75 \%$ of natural sciences committees did so.

TABLE 16.1

Percentage of Respondents Requesting Statements of Teaching Philosophy During the Hiring Process, by Institutional Type

\begin{tabular}{|c|c|c|c|}
\hline $\begin{array}{c}\text { Requested Teaching } \\
\text { Philosophy During } \\
\text { Hiring Process }\end{array}$ & Doctoral & Master's & Bachelor's \\
\hline Yes & $53.6 \%$ & $61.5 \%$ & $61.5 \%$ \\
\hline No & $46.4 \%$ & $38.5 \%$ & $38.5 \%$ \\
\hline
\end{tabular}

Note. Significance testing revealed no significant differences $(\mathrm{p}<.05)$ by institutional type. 


\section{TABLE 16.2}

Percentage of Respondents Requesting Statements of Teaching Philosophy During the Hiring Process, by Division

\begin{tabular}{|c|c|c|c|}
\hline $\begin{array}{c}\text { Requested Teaching } \\
\text { Philosophy During } \\
\text { Hiring Process }\end{array}$ & Humanities & Social Sciences & Natural Sciences ${ }^{*}$ \\
\hline Yes & $50.2 \%$ & $49.6 \%$ & $79.8 \%$ \\
\hline No & $49.8 \%$ & $50.4 \%$ & $20.2 \%$ \\
\hline
\end{tabular}

* Note. Results for the natural sciences are significantly different from those in the humanities and social sciences $(\mathrm{p}<.05)$.

It is clear from these responses that teaching statements are now commonly requested across the disciplinary and institutional spectrum. However, graduate students in our PFF Seminar often ask about the wisdom of sending an unsolicited teaching statement, and so our survey asked: "Based on your experience, how do you think a search committee would respond if the applicant submitted a statement of teaching philosophy even though a statement was not requested?" Respondents answered using a 6-point rating scale (from $1=$ Extremely Unfavorable to $6=$ Extremely Favorable) to express their views of unsolicited statements at three stages, the initial application, first-round interviews, and campus visits. Tables 16.3 and 16.4 report mean responses by institutional type and disciplinary division. At each stage, faculty viewed submission of an unsolicited statement in a generally positive light, with median responses of approximately 4.9 at each stage $(5=$ Favorable). Although there were slight differences by institutional type and disciplinary division, the overall conclusion remains unchanged: Submission of an unsolicited teaching statement is viewed quite positively by search committee chairs in our sample.

\section{What Makes a Successful Statement?}

In our survey, we asked search committee chairs to tell us what makes a statement of teaching philosophy successful or unsuccessful. Based on the responses, this is a topic of great interest to those who read teaching statements: $78 \%$ of respondents provided open-ended responses about successful statements and $76 \%$ about the unsuccessful ones.

In analyzing the 356 responses to the question "What makes a teaching statement successful?" we looked for common themes and language. We divided 
TABLE 16.3

Mean Favorability of a Candidate's Submission of an Unsolicited Teaching Philosophy, by Institutional Type

Respondents rated each item on a 6 -point Likert scale (6 = Extremely Favorable to $1=$ Extremely Unfavorable)

\begin{tabular}{|l|c|c|c|}
\hline \multicolumn{1}{|c|}{ Institutional Type^ } & $\begin{array}{c}\text { Initial } \\
\text { Application }\end{array}$ & $\begin{array}{c}\text { First-Round } \\
\text { Interview }\end{array}$ & $\begin{array}{c}\text { Campus } \\
\text { Visit }\end{array}$ \\
\hline Doctoral extensive & 4.73 & 4.70 & 4.79 \\
\hline Doctoral intensive & $5.05^{*}$ & $5.12^{*}$ & 5.05 \\
\hline Master's & $4.93^{*}$ & $4.93^{*}$ & 4.99 \\
\hline Bachelor's & $5.00^{*}$ & 4.89 & 4.90 \\
\hline Overall & 4.88 & 4.85 & 4.90 \\
\hline
\end{tabular}

$\wedge$ Note. Only differences between doctoral-extensive and other institutions were statistically significant at the $(\mathrm{p}<.05)$ level. These are indicated by an *.

TABLE 16.4

\section{Mean Favorability of a Candidate's Submission of an Unsolicited Teaching Philosophy, by Disciplinary Division}

Respondents rated each item on a 6 -point Likert scale $(6=$ Extremely Favorable to $1=$ Extremely Unfavorable)

\begin{tabular}{|l|c|c|c|}
\hline \multicolumn{1}{|c|}{ Division ^ } & $\begin{array}{c}\text { Initial } \\
\text { Application }\end{array}$ & $\begin{array}{c}\text { First-Round } \\
\text { Interview }\end{array}$ & $\begin{array}{c}\text { Campus } \\
\text { Visit }\end{array}$ \\
\hline Humanities & 4.81 & 4.90 & 4.98 \\
\hline Social sciences & 4.95 & 4.86 & 4.82 \\
\hline Natural sciences & 4.88 & $4.68^{*}$ & 4.80 \\
\hline Overall & 4.87 & 4.84 & 4.89 \\
\hline
\end{tabular}

$\wedge$ Note. Difference of means tests revealed statistically significant differences between the natural sciences and humanities during the first round $(\mathrm{p}<.05)$. 
these themes into five major categories and then coded each response based on these categories:

- Offers evidence of practice. Search committees wanted to see how effectively a candidate could instantiate the philosophy of teaching. They sought specific examples of how the applicant linked theory with their actual teaching experiences ( 110 responses). This was by far the most commonly cited trait of successful statements. For example, a respondent in political science said the following: "Statements are most effective when they include specific and personal examples, experiences, etc. It makes the statement seem more than merely perfunctory." Similarly, a faculty member in psychology valued statements that were "Succinct; included examples of enactment of the philosophy."

- Is student centered, attuned to differences in student ability, learning styles, or level ( 65 responses). For example, a faculty member in biology was looking for "Clear expression of methods of instruction that go beyond the traditional lecture and testing methodology. Active learning and group problem solving appreciation are two valued components."

- Demonstrates reflectiveness. Search committees sought evidence that the writer was a thoughtful instructor. They looked for examples about how changes had been made in the classroom, how the instructor had grappled with instructional challenges, and how the applicant outlined his or her future development as a teacher ( 53 responses). For example, "They showed that the candidate had given much thought to their goals and approaches to teaching" (chemistry); "Indications that the candidate had reflected on his/her past experiences" (English).

- Conveys valuing of teaching. Survey respondents appreciated a tone or language that conveyed an enthusiasm for teaching or a vision of the applicant as a teacher. Conversely, they devalued philosophies that conceptualized teaching as a burden, a requirement, or as less of a priority than research (50 responses). For example "Successful statements demonstrated the candidate's enthusiasm for teaching" (chemistry); "Enthusiasm for teaching usually manifests itself as well as indications that it is as serious an undertaking as one's scholarly pursuits" (English).

- Is well written, clear, readable (39 responses).

In our analysis of the 347 responses to the question "What makes a teaching statement unsuccessful?" two characteristics were mentioned most frequently: 
- Is generic, full of boilerplate language, does not appear to be taken seriously. By far the most commonly cited complaint was the use of jargon, buzzwords, or "teaching-philosophy speak" that made all statements sound alike and rather generic (134 responses). For example, "Failure to realize that much of what was in the statement was cliché" (history); "Tended to include all of the right 'buzz words' which made me wonder about the sincerity of the statement" (psychology); "Those that were formulaic, that seemed to include as many buzzwords as possible" (English).

- Provides no evidence of practice. Faculty wanted some sense that the ideas presented in the statement were actually grounded in the candidate's experience ( 74 responses). For example, "Most of it sounded highly theoretical and idealistic. I am not sure that the writers had ever tried some of those things with live students in actual classrooms" (history); "Global, vague statements that were not specific enough about exactly how the person would implement a teaching style" (psychology).

\section{The Rubric}

Clearly, the teaching statement is now a common part of faculty and graduate student work life. Just as obvious to us from our experience is the fact that academics are not prepared for this type of writing and, as a result, they find it difficult. The majority of our work on teaching statements occurs within the context of our month-long PFF Seminar, where one of the main requirements is the writing of a statement of teaching philosophy.

Unfortunately, during the first three years of the program (2000-2002) we were frequently disappointed with the quality of the statements participants were producing. These statements often sounded generic and theoretical, failing to convey the experiences and disciplinary contexts that emerged in discussions among the very talented graduate students in our program. Problems we were noting echoed issues raised by the faculty in our survey. The situation was particularly disheartening because the seminar already included several mechanisms to help participants develop successful statements, including readings, exercises for getting started, and feedback from peers in the seminar.

We began working on a rubric to make explicit to our PFF students our own perceptions of the strengths characteristic of effective teaching statements and the pitfalls to be avoided. Our assumption was that having a set of criteria would make the writing process more manageable. 
Research on rubrics supports our approach. A rubric can be defined as "a scoring tool that lays out the specific expectations for an assignment. Rubrics divide an assignment into its component parts and provide detailed description of what constitutes acceptable or unacceptable levels of performance for each of those parts" (Stevens \& Levi, 2005, p. 3). Andrade (1997) outlines four reasons why rubrics are effective, two of which are particularly applicable to our work with teaching statements. First, rubrics are useful for both teaching and assessment: "Rubrics can improve student performance ... by making teachers' expectations clear and by showing students how to meet these expectations." Second, rubrics promote self-regulated learning and help students to develop their own judgment: "When rubrics are used to guide self- and peerassessment, students become increasingly able to spot and solve problems in their own and one another's work" (Andrade, 1997). Rubrics have been shown to have positive impacts on high school and undergraduate students' writing and achievement (Andrade \& Du, 2005). One may reasonably expect that students' uses of rubrics-to determine expectations, plan production, facilitate revision, and guide and prompt reflection (Andrade \& Du, 2005) would be mirrored by graduate students and faculty as they learn to write in this unfamiliar genre.

As mentioned earlier, the rubric we constructed drew on our own experience critiquing hundreds of teaching philosophies as well as the survey of search committee members. Our primary goals when writing it were 1) to provide a concrete structure that prompted and facilitated reflection on the key components of an instructor's philosophy and the articulation of that philosophy, and 2) to bring to the fore those characteristics that search committees found most meaningful and successful.

As we worked to refine and improve the rubric over different iterations, we also kept in mind those qualities that define successful rubrics. Mullinix (2003) presents a "rubric for rubrics" that we found informative in judging our own. We aimed for a rubric that could be called "exemplary" in all the criteria presented: clarity of criteria and expectations, distinction between levels of achievement, inter-rater reliability, support of metacognition, and ease of use in peer and self-evaluation (see also Popham, 1997, for an excellent discussion of the qualities of effective and ineffective rubrics).

We should note here that ours is not the first rubric created for the evaluation of teaching statements. Schönwetter, Sokal, Friesen, and Taylor (2002) outline a rubric in their paper on the development and evaluation of teaching statements. However, this rubric focuses on the statement as an articulation of instructors' understanding of the teaching and learning literature, rather than 
the areas highlighted by our survey research (e.g., the importance of specific evidence of practice).

The rubric (see Appendix 16.1) provides weak, average, and excellent descriptors of five categories of teaching philosophy characteristics:

1. Goals for student learning

2. Enactment of goals

3. Assessment of goals

4. Creating an inclusive learning environment

5. Structure, rhetoric, and language

The first three categories of the rubric were framed by theories of alignment across instructor goals, methods, and assessments. Alignment is a major focus of our PFF Seminar, and we have found that this approach leads to teaching statements that offer the fullest picture of an instructor's approach to teaching and learning. This model has the added benefit of prompting instructors to reflect on the degree to which their methods and assessments actually do align with their goals. As one seminar participant wrote,

The rubric has actually gotten me thinking about my teaching and what I concentrate on in the classroom, in addition to developing a teaching philosophy statement. For example, how to reach all students in the class and how evaluation techniques tell me whether students are achieving goals.

Category 4 reflects our center's commitment to diversity and our belief that teaching that reaches students at the margins of the classroom is good for all students in the classroom. We have found this to be the most neglected component of teaching statements, and we have chosen to highlight this issue in its own category to draw particular attention to it. Descriptors for this category emphasize the integration of inclusive teaching and learning throughout the statement, thereby avoiding the isolated "diversity paragraph," another common weakness of teaching statements.

The last category (structure, rhetoric, and language) addresses some of the most common complaints about teaching statements. Descriptors for this category stress the elimination of teaching jargon that alienates many readers and weak thematic structures that make reading difficult.

A focus on specificity and disciplinary context is built into all of the categories in the rubric, and rich, illustrative examples are emphasized as well. For example, under "Enactment," the "Excellent" category includes the following 
descriptor: "Specific examples of the methods in use within the disciplinary context are given." A statement "needs work" in this category when "Methods are described but generically, [with] no example of the instructor's use of the methods within the discipline." Under "Structure, rhetoric, and language," excellence includes "Jargon is avoided and teaching terms (e.g., critical thinking) are given specific definitions that apply to the instructor's disciplinary context. Specific, rich examples are used to bolster statements of goals, methods, and assessments."

\section{How ls the Rubric Used?}

Because clients' needs differ depending on their rank and experience, as well as their disposition and ability to commit time to writing their teaching statement, the rubric is used as a consulting tool in a variety of different settings.

In individual consultations with graduate students and faculty, clients are typically interested in feedback on a teaching statement that they have already started. In this case, we typically ask clients to self-evaluate their own statement using the rubric. The consultant also evaluates the teaching statement before meeting the client, and the resulting consultation focuses on areas where the instructor and consultant agree and disagree and what the instructor needs to do to improve the statement in different categories of the rubric and holistically. Since beginning to use the rubric in this way we have noticed a drop in clients' anxiety about writing the statement and an increase in the quality of the teaching statements, even when our consultation clients were pressed for time (as is often the case).

The teaching philosophy rubric also forms the cornerstone of our 90 minute Teaching Philosophy Workshop. This workshop begins with a general introduction to the characteristics of the teaching statement, but then quickly introduces participants to the rubric. Within the first 15 minutes of the workshop, participants use the rubric to evaluate a sample teaching statement and use electronic classroom voting devices to rank the statement on each category of the rubric. We find that this anonymous voting helps workshop participants develop a shared understanding of how to use the rubric while leaving space for individual priorities and judgments as to the qualities of the statement most important to them. Due to the short length of this workshop, participants only have time to begin outlining their own teaching statements, but they have been effectively coached in using the rubric for evaluating their own statements.

The rubric is used most rigorously in our month-long PFF Seminar, held for 50 hours over 10 days in May each year. In this intensive workshop, 40-50 
advanced graduate students learn about higher education, participate in and reflect on advanced teaching techniques, and write a statement of teaching philosophy and a sample syllabus, both for use in job applications. The seminar's coverage of the teaching statement begins in much the same way as the Teaching Philosophy Workshop. We introduce the characteristics of the teaching statement and the rubric. Participants then use the rubric and electronic voting devices to evaluate sample teaching statements. Thanks to the length of the seminar, participants are able to write and receive feedback from colleagues on multiple drafts of their teaching statements. The rubric guides this feedback, especially during earlier drafts. In all iterations, drafts and feedback are posted online for the benefit of all seminar participants.

\section{Validation}

To assess potential differences in the quality of teaching statements before and after the implementation of the rubric, philosophies from two years of the PFF Seminar were chosen for evaluation. A random sample of 20 philosophies was selected from the pool of all 80 statements, stratified by usage of the rubric (pre- and post-implementation) and discipline (see Table 16.5).

TABLE 16.5

Disciplinary Representation of Teaching Statements in the Study Sample

\begin{tabular}{|l|c|c|c|c|}
\hline & \multicolumn{2}{|c|}{$\begin{array}{c}\text { Pre-Rubric } \\
\text { (2002) }\end{array}$} & \multicolumn{2}{c|}{$\begin{array}{c}\text { Post-Rubric } \\
\text { (2006) }\end{array}$} \\
\hline $\begin{array}{l}\text { Disciplinary } \\
\text { Grouping }\end{array}$ & $\begin{array}{l}\text { Number of All } \\
\text { Statements }\end{array}$ & $\begin{array}{c}\text { Number in } \\
\text { Study Sample }\end{array}$ & $\begin{array}{c}\text { Number of All } \\
\text { Statements }\end{array}$ & $\begin{array}{c}\text { Number in } \\
\text { Study Sample }\end{array}$ \\
\hline $\begin{array}{l}\text { Science, } \\
\text { technology, } \\
\text { engineering, } \\
\text { and math }\end{array}$ & 16 & 4 & 18 & 4 \\
\hline Social sciences & 11 & 4 & 9 & 2 \\
\hline $\begin{array}{l}\text { Arts and } \\
\text { humanities }\end{array}$ & 4 & 2 & 15 & 4 \\
\hline Totals & 31 & 10 & 42 & 10 \\
\hline
\end{tabular}


These 20 teaching statements were then assessed from the perspective of job search committees based on the survey mentioned earlier. As a reminder, the following criteria were ranked as the top important constituents of a teaching statement:

- Offers evidence of practice

- Is student centered, attuned to differences in student ability, learning styles, or level

- Demonstrates reflectiveness

- Conveys valuing of teaching

- Is well written, clear, readable

One of the authors (Wright), a consultant in the university's Center for Research on Learning and Teaching not involved in the construction of the rubric, applied each of these criteria to the 20 statements. Statements were presented anonymously so that the rater would have no knowledge of which statements belonged to which cohort. Each standard received a rating of 1 (poor, or not addressed in the statement), 2 (good, or present in the statement but not extensively developed or well executed), or 3 (excellent, or present in the statement and well developed and executed). These scores were combined into an "effective philosophy index." For example, a statement that perfectly addressed all job search committee criteria would merit a score of 15 .

Applying standards valued by job search committees, the evaluation of the 20 teaching statements found a dramatic increase in quality in the postrubric statements. Before the rubric-based workshop became part of the PFF Seminar, the average evaluation score was 9.7 (see Table 16.6). After the introduction of the rubric, scores averaged 11.7 , a statistically significant increase of 2.0 points $(\mathrm{p}<.05)$.

\section{TABLE 16.6}

Mean Evaluation Scores on the Effective Philosophy Index

\begin{tabular}{|c|c|c|c|}
\hline & $\begin{array}{c}\text { Pre-Rubric (2002) } \\
(\mathrm{SD})\end{array}$ & $\begin{array}{c}\text { Post-Rubric(2006) } \\
(\mathrm{SD})\end{array}$ & $\begin{array}{c}\text { Difference } \\
\text { in Means }\end{array}$ \\
\hline Overall Mean Score & $\begin{array}{c}9.7(\underline{2.5}) \\
\mathrm{N}=10\end{array}$ & $\begin{array}{c}11.7(2.3) \\
\mathrm{N}=10\end{array}$ & $2.0^{*}$ \\
\hline
\end{tabular}


To illustrate the dramatic change in quality in another manner, 7 out of the 10 lowest-scoring philosophies were from 2002, while 7 . out of the 10 highest-scoring philosophies were written in 2006. A more detailed analysis of the scoring reveals that the largest difference between the two years is found in the first category, "Offers evidence of practice" (2.7 mean in 2006 vs. 2.1 in 2002), a major focus of the rubric, while the smallest difference is found in the final category, "Is well written" ( 2.3 in 2006 vs. 2.1 in 2002), a more generic category that has less to do with the teaching philosophy than with the student's overall skill as a writer. Of the 10 statements from 2006, 8 were rated as excellent on evidence of practice, whereas only 4 received that rating in 2002 .

The following is a typical example of the excellent use of evidence in the 2006 statements, in which rich examples of practice within a specific disciplinary context are woven in throughout the statement. This humanities graduate student writes about the goals of having students develop the ability to do close reading and of using writing to make connections between texts:

Close reading: One way in which I try to "ease" students into close reading, then, is to pass out a small piece of familiar text.... I then begin to ask them questions about the text's specific imagery and diction, about the way its smaller elements work in service of an issue that surpasses their individual details. After modeling the close reading...I ask the class to spend 15 minutes writing notes for a close reading. ... Once students finish writing, we compile a list of their "close-reading notes" on the board. The result each time has been an extraordinarily diverse and creative group of ways of looking at a small piece of text.

Using writing to connect texts: I strive to engender a comparative spirit by requiring a variety of smaller writing assignments that concentrate on connecting individual readings ... to other texts or issues that are meaningful to class members. One way I specifically go about this is to ask students to pick an anecdote, newspaper or magazine article whose themes speak to those in a particular text and to write a short reflective essay on the relationship.... One memorable essay from an American Novel course looked at ...

The 2002 statements often have well-articulated ideas about teaching, but stop short of offering rich evidence for the implementation of these ideas. As a result, they tend to sound more generic, a main complaint of faculty in our survey. For instance, a student in the social sciences discusses the role of humor and the challenges of teaching core, multidisciplinary courses. While 
there are some examples, they are not nearly as rich or well developed, and they are not as firmly grounded in the discipline:

Humor: I do not mean that all learning sessions must require "fun and games." Rather I use humor as a way of setting the tone for a session, or as a device to break the tension and frustration when the going gets rough. My use of humor has evolved over the years, relying less on "jokes" and more on an overall sense of good nature ...

Core courses: Students from these courses come from a variety of backgrounds and, for the most part, are highly motivated to learn. We require students to quickly learn concepts from a variety of disciplines and this can lead to frustration.... At times I have acted as a "translator" between disciplines explaining concepts in plain terms and helping students to draw connections between disciplines. I have found myself needing to explain basic computer data structures to students with humanities backgrounds, or introducing the basic components of a particular sociological theory to computer scientists.

\section{Conclusion}

Not surprisingly (for anyone who has used rubrics in their own teaching and assessment), the rubric-based consulting approach results in teaching statements that are more closely aligned with search committees' judgments of quality. Anecdotally, we can also report that authors' anxiety in writing statements is greatly reduced when they can rely on the concrete guidance of the rubric. As with many other instructional development interactions, we have found that a consulting approach focused on reflection and self-discovery is much more effective than just telling instructors what makes for a good statement. The rubric is a useful tool for facilitating this reflection and growth, as it provides an obvious structure for framing and gauging that reflection.

We do not, however, claim that the rubric offers a one-size-fits-all solution. Institutions, disciplines, and individuals differ in how they envision effective teaching and learning and its articulation. Consultants should see the rubric as a flexible tool that they can shape to their institution's or individual client's needs. Likewise, instructors must attain some degree of comfort with the ambiguities of the genre. 
Finally, much, if not most, of our work on teaching statements has been with graduate students preparing for the job market. When applied to faculty teaching statements, the rubric-based approach raises some challenging questions for institutions. Should departments agree on a standard for teaching statements? How should statements be evaluated in tenure and promotion decisions? Should all faculty receive training in how to write in this unfamiliar genre? While it is unrealistic to expect that diverse and decentralized institutions such as ours could (or would want to) develop a uniform standard, individual departments might attempt to create their own rubrics for faculty teaching statements. This would provide faculty with a context-specific set of criteria and it would also open up a very significant conversation about the department's pedagogical values. 


\section{Appendix 16.1 \\ Rubric for Statements of Teaching Philosophy}

Developed by Matt Kaplan, Rosario Carillo, Chris O'Neal, Deborah Meizlish, \& Diana Kardia

Center for Research on Learning and Teaching, University of Michigan

\begin{tabular}{|l|l|l|l|}
\hline \multicolumn{1}{|c|}{$\begin{array}{c}\text { Possible } \\
\text { Components }\end{array}$} & \multicolumn{1}{|c|}{ Excellent } & \multicolumn{1}{c|}{ Needs Work } & \multicolumn{1}{c|}{ Weak } \\
\hline $\begin{array}{l}\text { Goals for Student } \\
\text { Learning: } \\
\text { What knowledge, } \\
\text { skills, and attitudes } \\
\text { are important for } \\
\text { student success in } \\
\text { your discipline? } \\
\text { What are you } \\
\text { preparing students } \\
\text { for? What are key } \\
\text { challenges in the } \\
\text { teaching-learning } \\
\text { process? }\end{array}$ & $\begin{array}{l}\text { Goals are clearly } \\
\text { articulated and } \\
\text { specific and go } \\
\text { beyond the } \\
\text { knowledge level, } \\
\text { including skills, } \\
\text { attitudes, career } \\
\text { goals, etc. Goals are } \\
\text { sensitive to the } \\
\text { context of the } \\
\text { instructor's } \\
\text { discipline. They are } \\
\text { concise but not } \\
\text { exhaustive. }\end{array}$ & $\begin{array}{l}\text { Goals are articulated } \\
\text { although they may } \\
\text { be too broad or not } \\
\text { specific to the } \\
\text { discipline. Goals } \\
\text { focus on basic } \\
\text { knowledge, ignoring } \\
\text { skills acquisition and } \\
\text { affective change. }\end{array}$ & $\begin{array}{l}\text { Articulation of goals } \\
\text { is unfocused, } \\
\text { incomplete, or } \\
\text { missing. }\end{array}$ \\
\hline $\begin{array}{l}\text { Enactment of Goals } \\
\text { (teaching methods): } \\
\text { What teaching } \\
\text { methods do you use? } \\
\text { How do these } \\
\text { methods contribute } \\
\text { to your goals for } \\
\text { students? Why are } \\
\text { these methods } \\
\text { appropriate for use } \\
\text { in your discipline? }\end{array}$ & $\begin{array}{l}\text { Enactment of goals } \\
\text { is specific and } \\
\text { thoughtful. Includes } \\
\text { details and rationale } \\
\text { about teaching } \\
\text { methods. The } \\
\text { methods are clearly } \\
\text { connected to specific } \\
\text { goals and are } \\
\text { appropriate for those } \\
\text { goals. Specific } \\
\text { examples of the } \\
\text { method in use } \\
\text { within the } \\
\text { disciplinary context } \\
\text { are given. }\end{array}$ & $\begin{array}{l}\text { Description of } \\
\text { teaching methods } \\
\text { not clearly connected } \\
\text { to goals or if } \\
\text { connected, not well } \\
\text { developed (seems } \\
\text { like a list of what is } \\
\text { done in the } \\
\text { classroom). Methods } \\
\text { are described but } \\
\text { generically, no } \\
\text { example of the } \\
\text { instructors use of } \\
\text { the methods within } \\
\text { the discipline is } \\
\text { communicated. }\end{array}$ & $\begin{array}{l}\text { Enactment of goals is } \\
\text { not articulated. If } \\
\text { there is an attempt at } \\
\text { articulating teaching } \\
\text { methods, it is basic } \\
\text { and unreflective. }\end{array}$ \\
\hline
\end{tabular}




\begin{tabular}{|c|c|c|c|}
\hline $\begin{array}{c}\text { Possible } \\
\text { Components }\end{array}$ & Excellent & Needs Work & Weak \\
\hline $\begin{array}{l}\text { Assessment of Goals } \\
\text { (measuring student } \\
\text { learning): } \\
\text { How do you know } \\
\text { your goals for } \\
\text { students are being } \\
\text { met? What sorts of } \\
\text { assessment tools do } \\
\text { you use (e.g., tests, } \\
\text { papers, portfolios, } \\
\text { journals), and why? } \\
\text { How do assessments } \\
\text { contribute to student } \\
\text { learning? How do } \\
\text { assessments } \\
\text { communicate } \\
\text { disciplinary } \\
\text { priorities? }\end{array}$ & \begin{tabular}{|l} 
Specific examples of \\
assessment tools are \\
clearly described. \\
Assessment tools are \\
aligned with \\
teaching goals and \\
teaching methods. \\
Assessments \\
reinforce the \\
priorities and \\
context of the \\
discipline both in \\
content and type.
\end{tabular} & $\begin{array}{l}\text { Assessments are } \\
\text { described, but not in } \\
\text { connection to goals } \\
\text { and teaching } \\
\text { methods. } \\
\text { Description is too } \\
\text { general, with no } \\
\text { reference to the } \\
\text { motivation behind } \\
\text { the assessments. } \\
\text { There is no clear } \\
\text { connection between } \\
\text { the assessments and } \\
\text { the priorities of the } \\
\text { discipline. }\end{array}$ & $\begin{array}{l}\text { Assessment of goals } \\
\text { is not articulated or } \\
\text { mentioned only in } \\
\text { passing. }\end{array}$ \\
\hline $\begin{array}{l}\text { Creating an } \\
\text { Inclusive Learning } \\
\text { Environment, } \\
\text { Addressing One or } \\
\text { More of the } \\
\text { Following } \\
\text { Questions: } \\
\text { How do your own } \\
\text { and your students' } \\
\text { identities (e.g., race, } \\
\text { gender, class, } \\
\text { background, } \\
\text { experience, and } \\
\text { levels of privilege) } \\
\text { affect the classroom? } \\
\text { How do you account } \\
\text { for diverse learning } \\
\text { styles? How do you } \\
\text { integrate diverse } \\
\text { perspectives into } \\
\text { your teaching? }\end{array}$ & $\begin{array}{l}\text { Portrays a coherent } \\
\text { philosophy of } \\
\text { inclusive education } \\
\text { that is integrated } \\
\text { throughout the } \\
\text { philosophy. Makes } \\
\text { space for diverse } \\
\text { ways of knowing } \\
\text { and/or learning } \\
\text { styles. Discussion of } \\
\text { roles is sensitive to } \\
\text { historically } \\
\text { underrepresented } \\
\text { students. } \\
\text { Demonstrates } \\
\text { awareness of issues } \\
\text { of equity within the } \\
\text { discipline. }\end{array}$ & $\begin{array}{l}\text { Inclusive teaching is } \\
\text { addressed but in a } \\
\text { cursory manner or in } \\
\text { a way that isolates it } \\
\text { from the rest of the } \\
\text { philosophy. Author } \\
\text { briefly connects } \\
\text { identity issues to as- } \\
\text { pects of his or her } \\
\text { teaching. }\end{array}$ & $\begin{array}{l}\text { Issues of inclusion } \\
\text { are not addressed or } \\
\text { addressed in an awk- } \\
\text { ward manner. There } \\
\text { is no connection to } \\
\text { teaching practices. }\end{array}$ \\
\hline
\end{tabular}




\begin{tabular}{|c|c|c|c|}
\hline $\begin{array}{c}\text { Possible } \\
\text { Components }\end{array}$ & Excellent & Needs Work & Weak \\
\hline $\begin{array}{l}\text { Structure, Rhetoric, } \\
\text { and Language: } \\
\text { How is the reader en- } \\
\text { gaged? Is the lan- } \\
\text { guage used } \\
\text { appropriate to the } \\
\text { discipline? How is } \\
\text { the statement the- } \\
\text { matically structured? }\end{array}$ & $\begin{array}{l}\text { The statement has a } \\
\text { guiding structure } \\
\text { and/or theme that } \\
\text { engages the reader } \\
\text { and organizes the } \\
\text { goals, methods, and } \\
\text { assessments articu- } \\
\text { lated in the state- } \\
\text { ment. Jargon is } \\
\text { avoided and teaching } \\
\text { terms (e.g., critical } \\
\text { thinking) are given } \\
\text { specific definitions } \\
\text { that apply to the in- } \\
\text { structor's discipli- } \\
\text { nary context. } \\
\text { Specific, rich exam- } \\
\text { ples are used to bol- } \\
\text { ster statements of } \\
\text { goals, methods, and } \\
\text { assessments. Gram- } \\
\text { mar and spelling are } \\
\text { correct. }\end{array}$ & $\begin{array}{l}\text { The statement has a } \\
\text { structure and/or } \\
\text { theme that is not } \\
\text { connected to the } \\
\text { ideas actually dis- } \\
\text { cussed in the state- } \\
\text { ment, or organizing } \\
\text { structure is weak and } \\
\text { does not resonate } \\
\text { within the discipli- } \\
\text { nary context. Exam- } \\
\text { ples are used but } \\
\text { seem generic. May } \\
\text { contain some jargon. }\end{array}$ & $\begin{array}{l}\text { No overall structure } \\
\text { present. Statement is } \\
\text { a collection of dis- } \\
\text { connected thoughts } \\
\text { about teaching. Jar- } \\
\text { gon is used liberally } \\
\text { and not supported by } \\
\text { specific definitions } \\
\text { or examples. Needs } \\
\text { much revision. }\end{array}$ \\
\hline
\end{tabular}




\section{References}

Andrade, H., \& Du, Y. (2005, April). Student perspectives on rubric-referenced assessment. Practical Assessment, Research and Evaluation, 10(3), 1-11.

Andrade, H. G. (1997). Understanding rubrics. Educational Leadership, 54(4). Retrieved May 21, 2007, from the Harvard Graduate School of Education, Active Learning Practices for Schools web site: http://learnweb.harvard.edu/ALPS/ thinking/docs/rubricar.htm

Chism, N. V. N. (1997-1998). Developing a philosophy of teaching statement. Essays on Teaching Excellence, 9(3) 1-2.

Cook, C. E., Kaplan, M., Nidiffer, J., \& Wright, M. C. (2001, March). Preparing future faculty-faster: A crash course guides students to the professoriate. AAHE Bulletin, 54(3), 3-7.

Coppola, B. (2000). How to write a teaching philosophy for academic employment. American Chemical Society, Department of Career Services Bulletin, 1-8.

Ellis, D., \& Griffin, G. (2000). Developing a teaching philosophy statement: A special challenge for graduate students. Journal of Graduate Teaching Assistant Development, $7(1), 85-92$.

Goodyear, G. E., \& Allchin, D. (1998). Statements of teaching philosophy. In M. Kaplan \& D. Lieberman (Eds.), To improve the academy: Vol. 17. Resources for faculty, instructional, and organizational development (pp. 103-121). Stillwater, OK: New Forums Press.

Meizlish, D. S., \& Kaplan, M. (2007). Valuing and evaluating teaching in academic hiring: A multi-disciplinary, cross institutional study. Manuscript submitted for publication.

Montell, G. (2003, March 27). What's your philosophy on teaching, and does it matter? The Chronicle of Higher Education. Retrieved May 21, 2007, from http://chronicle.com/jobs/2003/03/2003032701c.htm

Mullinix, B. B. (2003). A rubric for rubrics. Retrieved May 21, 2007, from the Monmouth University, Faculty Resource Center web site: http://its.monmouth .edu/facultyresourcecenter/Rubrics/A\%20Rubric\%20for\%20Rubrics.htm

Popham, W. J. (1997, October). What's wrong —and what's right—with rubrics. Educational Leadership, 55(2), 72-75.

Pratt, D. D. (2005, January-February). Personal philosophies of teaching: A false promise? Academe, 91(1), 32-35. 
Schönwetter, D. J., Sokal, L., Friesen, M., \& Taylor, K. L. (2002, May). Teaching philosophies reconsidered: A conceptual model for the development and evaluation of teaching philosophy statements. International Journal for Academic Development, $7(1), 83-97$.

Stevens, D. D., \& Levi, A. J. (2005). Introduction to rubrics: An assessment tool to save grading time, convey effective feedback, and promote student learning. Sterling, VA: Stylus. 